\title{
Implementation of School Literacy Program In Junior High School Muhammadiyah Palangka Raya
}

\author{
Feri Wagiono $^{1)}$, Offeny $^{2)}$, Eli Karliani ${ }^{3)}$ \\ Education study Program of Pancasila and Citizenship FKIP University of Palangka Raya, Jl. Yos \\ sudarso Tunjung Nyahoo, Palangka Raya, Indonesia ${ }^{1,2,3}$ \\ wagionoferi456@gmail.com ${ }^{1)}$, karlias2@yahoo.com ${ }^{3)}$
}

\begin{abstract}
This research on implementing school literacy programs, supporting factors, and inhibiting the implementation of school literacy program students and solutions are done by the school in overcoming the barriers to implementation of the Student literacy program in SMP Muhammadiyah Palangka Raya. The culture of reading through school literacy is a step in the student's character growth. This research uses qualitative methods, based on the fact that goes on now. Data collection techniques using interviews, observations, and documentation. Data analysis techniques used are data reduction, data presentation then draw conclusions or data verification. The results of the authors ' research led to the conclusion that: (1) Implementation of school literacy phase of habituation is 15 minutes reading non-book lessons, the development stage is to increase the reading ability by analyzing the books read, the learning stage is followed by analyzing and providing academic bills and increase the confidence of students through habituation and vigorous reading that was programmed by SMP Muhammadiyah Palangka Raya, (2) supporting factors and inhibitors of literacy activities in SMP Muhammadiyah Palangka Raya, infrastructure facilities, book library facility adequate, book donation of parents, teachers, and alumni, students are still minimal culture reading and late to class, (3) The solution motivates the students to follow the activities well, give direction or rebuke, appealed to all the school citizens whether teachers or students to love reading and writing to be a literate person.
\end{abstract}

Keywords: Implementation, School literacy of programs, SMP Muhammadiyah Palangka Raya

\begin{abstract}
Abstrak. Penelitian ini tentang implementasi program Literasi Sekolah, faktor pendukung dan penghambat implementasi program Literasi Sekolah siswa dan solusi dilakukan pihak sekolah dalam mengatasi hambatan implementasi program literasi siswa di SMP Muhammadiyah Palangka Raya. Pembudayaan membaca melalui Literasi Sekolah menjadi suatu langkah dalam penumbuhan budi pekerti siswa. Penelitian ini menggunakan metode kualitatif, didasarkan atas kenyataan yang berlangsung sekarang. Teknik pengumpulan data menggunakan wawancara, observasi dan dokumentasi. Teknik analisis data yang digunakan yaitu reduksi data, penyajian data kemudian penarikan kesimpulan atau verifikasi data. Hasil penelitian penulis mengarah kepada kesimpulan yaitu: (1) implementasi literasi sekolah tahap pembiasaan yaitu 15 menit membaca buku non-pelajaran, tahap pengembangan yaitu meningkatkan kemampuan membaca dengan menganalisis buku yang dibaca, tahap pembelajaran yaitu dilanjutkan dengan menganalisis serta pemberian tagihan akademik dan meningkatkan kepercayaan diri siswa melalui pembiasaan dan giat membaca yang diprogramkan oleh SMP Muhammadiyah Palangka Raya, (2) Faktor pendukung dan penghambat kegiatan literasi di SMP Muhammadiyah Palangka Raya, sarana prasarana, fasilitas buku perpustakaan memadai, progam sumbangan buku dari orang tua, guru dan alumni, siswa masih minim budaya membaca dan terlambat ke kelas, (3) Solusi memotivasi siswa mengikuti kegiatan dengan baik, memberikan arahan atau teguran, menghimbau kepada seluruh warga sekolah baik guru atau siswa untuk gemar membaca dan menulis agar menjadi pribadi yang literat.
\end{abstract}

Kata Kunci: Implementasi, Program Literasi Sekolah, SMP Muhammadiyah Palangka Raya 


\section{INTRODUCTION}

Reading for people is a boring activity even though many benefits can be obtained from reading. These benefits are not only intellectual aspects but also aspects of effectiveness and conscience. From an intellectual aspect, the benefits of reading are adding knowledge, vocabulary, and inspiration. While from the affective aspect, the benefits of reading can increase one's maturity in thinking and acting, as well as fostering concern for others (Lestari, 2016). Literacy culture includes the habit of reading, it has not yet become a culture in Indonesia. Based on the study "Most Littered Nation in the World" conducted by Central Connecticut State University in March 2018, Indonesia was ranked 60th out of 61 countries about reading interest. This fact is very alarming, especially if you see that in terms of assessment infrastructure, Indonesia's ranking is above European countries (Gewati, 2016).

The data corroborate the results of the Central Statistics Agency (BPS) census of the NationalSurvey Statistics Publication 2015Socio-Economic which shows that (91.47\%) people Indonesian choose to watch television rather than listen to the radio (7.54\%) and read newspapers or magazines ( $13.11 \%)$ and reading electronic news (18.89\%) (Kemendikbud, 2016). The data above shows the literacy culture of Indonesian society is still low and educational institutions play a role in fostering literacy culture, especially in schools.
Schools as a place to gain knowledge have not fully developed a culture of reading and writing or what is called literacy culture. Literacy culture should be an integral part of student self-development not yet cultivated in schools. It was seen when the school break bell rang, students would choose the school canteen as a place to spend time off rather than to the library (Supiandi, M.I \& Julung, 2016).

Books are a window to the world, various knowledge can be known and learned. Books as nutrition for a healthy soul, like food always supplies energy for the body. It's so important the role of books in human life, but in reality in this global era many students are still reluctant to read books. Reading becomes very heavy work for students, and it is quite underestimated because it is considered unattractive compared to online games and other modern games. Not surprisingly, according to the results of the Program for International Student Assessment (PISA), 2018 Indonesia is ranked 6th from the bottom of the order of 74 of 79 countries in the world in reading. Indonesia's average score is 371 , which is below that of Panama, which has an average score of 377 . Even though the world average score is 487 , it means that Indonesia's reading aspect is far below average (Hidayatullah.P, 2019).

The existence of books is not something interesting that has been displaced by online games, gadgets, and other modern games. 
Although in this modern era there are e-books, the application offers a variety of even thousands of titles that can be downloaded easily by readers, but the user's $e$-book must go through the internet to get it. This is different from books having more efficiency values, namely books can be carried everywhere and to read them, they do not need to use a laptop or gadget and do not have to be connected to the internet. Every student's interest in reading can be built through his habits. In reading, it is very necessary to have the intention to gain knowledge, insight, and knowledge. Reading habits are obtained from everyday experience, created from habits in the family and school. School as a place strategic foster reading habits for students (Emi, 2015).

As Muslims speak literacy, it turns out that there is a connection with the Holy Qur'an derived from the word qara'a, which means to read or read, so that the Qur'an is the word of Allah, revealed by the obligation to read to His servants. Referring to the sound of verse one iqra (read) which is a call to read to the Prophet which means to be a call for his people, followed by the fourth verse that teaches humans with intermediaries qalam (pen or writing) it is very clear that Islam calls on people to always read and write. That is how Islam interprets the activity of reading and writing as an important medium for humans. From the essence of the above verse provides inspiration and motivation, but the tradition of reading and writing has not been widely practiced by people in the days of His Majesty the Prophet Muhammad, His Majesty himself had never studied literacy, although some of his family and friends could write until finally the first revelations came down and The prophet ordered several friends to write down verse after verse that went down continuously (Romdhoni Ali, 2013).

The legal basis of School Literacy is guided by the Minister of Education and Culture Regulation (Permendikbud) No. 23 of 2015 concerning Development of Characteristics that schools should be a comfortable and inspirational place for students, teachers, and education personnel, habituating positive attitudes and behaviors in schools is a reflection from Pancasila values and should be part of the learning process and culture in schools. Minister of Education and Culture Regulation No. 23 of 2015 initiating reading activities fifteen minutes before entering the classroom is important in developing the culture of reading through School Literacy to be a vehicle for the growth of student's character.

Based on the results of observations made by the author that the school educational institutions in Palangka Raya namely Muhammadiyah Junior High School Palangka Raya have carried out literacy movements like other schools in general and the school also has an adequate library. Based on the description above, the writer is interested in studying: (1) 
the implementation of the literacy program for school students in Muhammadiyah Palangka Raya Junior High School, (2) factors that support and hinder the implementation of school literacy programs in Muhammadiyah Palangka Raya Junior High School, and (3) solutions by the school in overcoming obstacles to the implementation of the school literacy program at SMP Muhammadiyah Palangka Raya.

\section{RESEARCH METHODS}

Qualitative research is a type of research that produces descriptive data in the form of words that are written or oral form people and observable behavior. Researchers describe the phenomena and objects, namely the implementation of the School Literacy program. This research produces descriptive data in the form of written words which are a description of a person's observed behavior, which produces a description of the implementation of the School Literacy program at SMP Muhammadiyah in Palangka Raya. Sources of data in this study include primary data that are the words and actions of those observed or interviewed (Moser \& Korstjens, 2018). Primary data such as written records, audiotapes, and photo taking. Primary data obtained through interviews with respondents and informants. Secondary data were obtained from books, scientific magazines, archival sources, personal documents, and official documents (Lion, E. dan Helmuth Y. Bunu, 2013). Secondary data from literature books relating to the implementation of the program School Literacy at SMP Muhammadiyah Palangka Raya. Research data collection techniques such as interviews, observation, and documentation. Data analysis techniques using data collection, data reduction, data presentation then drawing conclusions or data verification.

\section{DISCUSSION}

As we know the policy is meaningless if it is not implemented. Implementation becomes one of the stages in the policy cycle. Van Meter \& Van Horn (Sudiyono, 2007) describes the implementation of policies as actions taken by the state, government, private sector, groups, and individuals in achieving goals that are the priority in policy decisions. Implementation is all actions taken between the process of formulating and evaluating policies. It has a similar view regarding implementation. Both figures revealed that the implementation was interpreted as an effort to implement a policy decision. "Implementation is a carrying out of basic policy decision, usually incorporated in a statute but which can also take the form of important court decisions decision. Ideally, that decision identifies the problem to be addressed, stipulates to the objectives to be pursued, and in a variety of ways, structure the implementation process." (Tilaar, 2008). Implementation is the 
implementation of basic policy decisions usually in the form of laws, but can also take the form of orders or executive important decisions or judicial decisions. According to Suprayitno (2019), public policy has an important role in managing public order both at the center and in the regions (Suprayitno S., Tulis, R. S., \& Zuraida, I., 2019).

According to George C. Edwards III in Subarsono (2008), policy implementation is influenced by four variables, namely; a) Communication, related to how policies are communicated and communicated to organizations and the public. The aims and objectives of the policy are conveyed to avoid distortions in implementation and resistance.

2) Resources, related to the availability of supporting resources in the form of HR, namely the implementer's competence, and financial resources. 3) Disposition, related to the character and characteristics of the implementation, such as commitment, honesty, and democratic nature. 4) Bureaucratic structure, related to the suitability of the organization implementing the policy implementation. The organizational structure of policy implementers has a significant influence on policy implementation. One aspect of the organizational structure is the existence of standard operating procedures (Standard Operating System or SOP) to guide every implementer in acting (Subarsono, 2008).

Arif Rohman (2012), states that there are determinants of success and failure of policy implementation. Supporting factors are factors or causes of the occurrence of something supportive or justifying, while the inhibiting factor is the cause of the failure of a desired (Setiawan \& Saefulloh, 2019). These factors consist of; 1) The formulation of policies made by decision-makers, can determine the success or even failure of the implementation of the policy. This concerns the clarity of the formulation sentence, accuracy of objectives, the accuracy of targets, ease in interpreting and understanding as well as difficulties in implementing them; 2) Factors implementing personnel determine the success of the implementation of policies in the form of levels of education, experience, motivation, commitment, loyalty, work ethic, socio-cultural, self-confidence and ability to cooperate. 3) The organization system is Implementing related to organizational structure, division of authority, and division of work tasks. It is also related to organizational leadership, organizational policies, and monitoring and model evaluation. Implementing policies need to fulfill these three factors so that policy implementation can go as expected (Rohman, 2012).

School Literacy in the context of the School Literacy Movement (GLS) is the ability to access, understand, and use something intelligently through various activities, including reading, seeing, listening, writing and or speaking. The School Literacy 
Movement (GLS) is an effort comprehensive to make schools a learning organization whose citizens are literate for life through public engagement. Then we are familiar with the term education life long (long life eduction). Life long learning process runs if everyone has a culture of reading and writing or known as literacy (Kalida, Muhsin \& Moh. Mursyid, 2015).

Writing activity unwittingly turns out to be a criterion for the progress of a nation. Many of the nation's advances have become extinct and are not recognized to date because there is no literature found. The progress of science and technology itself cannot be separated from writing activities. Then the activity of collecting ideas by writing will give birth to works that will continue to be collected, read, applied, and corrected by their successors. In the Islamic concept as mentioned in Surah $\mathrm{Al}$ alaq, it is not only moving the culture of reading (Iqra 'verse 1) but it is far from verse 4 Islam interpreting writing activities as an important medium in human life. A culture good reading must have a strong filter, one of which is the search for insight through the internet (Saefulloh, 2018). In the QS Al alaq "who teaches (human) with intermediaries qalam (pen, writing)" it is very clear, that the existence of Islam has a message inviting people to read and write. This verse also teaches writing as a means of the process of transformation of knowledge. As stated (Kalida, Muhsin \& Moh. Mursyid, 2015) that writing clears the mind. When someone experiences a problem, then writes down all the problems, it turns out to have a positive impact to clear the mind, this is one of the functions of muhasabah in Islam (Saefulloh, 2018a). Of course this makes writing a therapy. By writing down the trauma a person has experienced, it will easily be overcome. Writing helps and obtains and remembers information, learning by writing will make memory much sharper. Writing can also make the brain nerve more active so that one can remember more of the lessons learned.

School literacy is an activity responding to books that have been read (the development stage) providing opportunities for students to express their thoughts and feelings about the book being read. This activity can also reveal whether students like the books they read, can capture the themes and main ideas in the book, understand the elements of the story and the confidence to speak in front of the class. Before teachers do the teacher must give examples of how to summarize, retell, and respond to the contents of the book, the importance of the role of a teacher in managing effective learning for students (Saefulloh, 2018b). This example can be done during the activity of reading silently and reading a loud at the stage of habituation and development. Thus, at the development stage, students already know how to summarize, retell, and respond to the contents of the book orally and in writing. 
Schools are at the fore front in the growth of literacy culture. Beers in (Wiedarti, 2016) conveys strategies to create a culture of good literacy in schools. These strategies consist of; 1) Creating a literacy-friendly physical environment, schools can display student work in the school area as a form of appreciation motivated to read;2) Creating a social and affective environment as a literal model of communication and interaction with festivals educational and awards for student achievement. The form of appreciation can be directed to things that can increase student literacy such as book giving; 3) Creating a school as environment a literal academic, physical, social and affective environment related to school as anenvironment academic, namely the allocation of time for habituation.

\section{Implementation of School Literacy Program in SMP Muhammadiyah Palangka Raya}

This research was conducted to find out the implementation of school literacy in SMP Muhammadiyah Palangka Raya. Literacy culture is interpreted as a culture of reading by the citizens of SMP Muhammadiyah Palangka Raya. SMP Muhammadiyah Palangka Raya believes that according to Minister of Education and Culture Regulation (Permendikbud) No. 23 of 2015 to initiate 15 minutes of reading every day before entering the classroom it is very important in the character of reading through School Literacy as the growth of students' character (NS, interview 30 April 2019). SMP Palangka Raya Muhammadiyah considered that literacy culture was important to be instilled especially students. Literacy culture as a benchmark shapes the character of the young generation ready mentally in facing the era of globalization or the era of dynamic gadgets (FM, interview 30 April 2019). Benefits that can be obtained by students from literacy culture such as increasing knowledge student, practicing coherent speaking skills, sensitivity and self-confidence of students and influencing students' mindset (AWA, interview 30 April 2019).

SMP Muhammadiyah Palangka Raya decided to advancehours school. The time obtained from this decision is used for reading activities before the lesson. The school which initially entered at $07.00 \mathrm{WIB}$, since 4 years ago in 2015 after the Education issuance of the Republic of Indonesia Minister of Regulation No. 23 of 2015 on the Growth of Characteristics decided to advance school hours to 06.45 to 07.25 WIB (WG, interview May 14, 2019). Muhammadiyah Palangka Raya Junior High School showed that the first time instructions from the Ministry of Education and Culture of RI dropped out of school directly followed up. School follow-up is to make a strategy that is to allocate time for literacy activities. The allocation is obtained by advancing school entry time. After advancing time to enter the school, the first 
hour is used for literacy activities. This is in line with Mrs. NS, that the SMP Muhammadiyah Palangka Raya is a school characterized by the Islamic Religion now plus its literacy program namely the Qur'an and reading books for all classes at the same time 40 minutes is held on Monday, Tuesday and Wednesday (NS, interview 30 April 2019 ).

SMP Muhammadiyah Palangka Raya has an extracurricular wall magazine called student creativity activities to improve students' writing abilities. SMP Muhammadiyah Palangka Raya has wall magazine extracurricular activities. The activity was to improve students 'ability to write and to accommodate students' talents and interests in the world of writing (BR, interview 16 May 2019). The existence of these activities also aims to instill and foster a literacy culture in the school. Next is the procurement of the school library.

A form of readiness in implementing the School Literacy program, SMP Muhammadiyah Palangka Raya Muhammadiyah has tried to provide convenient school library facilities (MAS, 30 April 2019). The SMP Muhammadiyah Palangka Raya library has been felt comfortable by students. SMP Muhammadiyah Palangka Raya library has a collection of readings consisting of textbooks, literature, religion, folklore, stories of the prophet (Sirah prophet), encyclopedias to comics can be found in the library although it is still inadequate. The school has a special budget for library management which includes the procurement of student reading books $(\mathrm{SH}$, interview 29 April 2019).

Based on the observations of the author, it shows that the class library is in the form of a small, modest shelf used specifically for placing and storing a collection of books class. The collection is books that are brought by students from their respective homes. The school supports library infrastructure, especially the provision of class libraries. Then the activity of reading a book for 15 minutes or called Giat reading. (HZ, interview May 14, 2019).

SMP Muhammadiyah Palangka Raya involves parents in supporting the implementation of the School Literacy program. One form of parent involvement is manifested in helping schools provide reading books for active reading activities. The book will later be stored in the class library, used for active reading activities. Every 6 months and when announcing the graduation of class IX students will be asked to bring donations of 23 reading books to the school library so that parents will provide reading books for their children (WG, interview 13 May 2019).

The role of the teacher in School Literacy aims to increase understanding through books that have been read visible during library visit activities. Library visit integrated with learning is a visit made for the sake of learning for example to do tasks related 
to the library, such as summarizing books, making reviews, and so on. When this visit takes place the teacher will accompany the students to condition the students during their activities in the library. Visits are not integrated learning, namely visits made by students outside of learning, for example student visits during empty hours. When there are hours empty, students are often directed to read books in the library. Every student who visits the library first takes off their shoes and then enters the library. After entering, they must fill in the attendance book provided by the officer. After filling out the book, they can immediately choose the book they are looking for. Library collection books are arranged on bookshelves according to categories such as storybooks, novels, knowledge, and encyclopedias making it easier for students to find books. After finding the book they are looking for, they can immediately read it. The size of the library is wide enough to make students free when reading books. Students can comfortably read books, because the school has also equipped the library with facilities such as reading tables, chairs, carpets, decorative flowers, LCDs, and fans.

Making a wall magazine in each subject is a form of the strategy carried out by the teacher in the classroom. The teacher often invites students to make bulletin boards in accordance with learning. For example, a bulletin board on the invitation to read motivation and three-dimensional wall magazine. This bulletin is not only for training student's ability in writing but also as a learning medium for students. Self-confidence students are trained to tell stories in class, especially in front of their friends and teachers when learning is seen in the library hours. During the library, hours are also a routine program in SMP Muhammadiyah Palangka Raya. Each class is given time each week during the lesson to read and borrow books in the library. Students are also required to borrow library books during these library hours.

School efforts in fostering interest in reading through School Literacy can be seen when activities reading before the lesson (Giat Reading). This program is carried out every morning from 06.45 to 07.25 WIB. Each class will have three times a schedule of active reading activities. Students are accustomed to reading books outside of textbooks and the Koran. The aim is to foster interest in reading and reading habits of students. Books that are used for the Active Reading program can be taken from a library collection or books that students bring from home.

Giving book prizes to outstanding students to foster student interest in reading through the School Literacy Movement. The school holds a competition between students. Criteria for diligent students, achievers and often visit the library to read books are given a reward or gift to motivate students to read. The program includes initiatives from the principal 
school and library official at SMP Muhammadiyah Palangka Raya to improve the culture literacy in his school. Gift giving is usually done when distributing report cards. Every student who excels will get a trophy and coaching money from school, and also getprize of a reading book. This is solely as a form of appreciation and motivation for student achievement.

The above strategy can be applied by schools that want to foster a literacy culture through the School Literacy Program. The implementation of the School Literacy program at SMP Muhammadiyah Palangka has several strategies consisting of (1) advancing school hours of reading, (2) providing convenient library facilities, (3) making wall magazines in each subject and (4) parents providing book facilities for students. Based on these strategies and then lowered into several programs such as, (1) Library hours,

(2) extracurricular wall magazine activities,

(3) Giving prizes or rewards to high-achieving students, (4) Reading activities before lessons or activities Reading, (5) Library visits, (6) Procurement of class libraries, (7) Procurement of library book collections.

School strategies and programs above if related to the strategy of building a culture of literacy in schools as proposed by the government, it can be described as consists of (1) Creating a literacy-friendly physical environment. This strategy was implemented by SMP Muhammadiyah Palangka Raya such as providing convenient library facilities and procurement of book collections. This can be seen from the library procurement program and collection of books andprocurement class library; (2) Creating a social and affective environment as a model of literacy communication and interaction. Strategy this is carried out by SMP Muhammadiyah Palangkaraya as mading in each subject, involving parents providing book facilities. This based program consists of visits library, pre-lesson reading activities (Giat Reading), magazine extracurriculars wall and rewards book for outstanding students; (3) Creating schools as literate academic environments. This strategy is seen in allocating time for literacy culture and advancing school hours. Allocating time libraryand reading habits such as reading activities are expected to improve literacy skills of school residents.

\section{Supporting and Inhibiting Factors of the Implementation of the School Literacy SMP Program Muhammadiyah Palangka}

\section{Raya}

Regarding the supporting factors of the existence of the School Literacy program in the Muhammadiyah Junior High School it is Palangka Rayaquite well programmed and has the support of various parties both teachers, students and parents. Through this view, school residents can carry out any programs or literacy activities in their schools. The 
common vision and views between policy implementers are indeed very important for the smooth implementation of a policy.

Compliance with and adherence to the Republic of Indonesia Minister ofRegulation No. 23 of 2015 concerning the Education Development of Character and School Literacy Guidelines. SMP Muhammadiyah Palangkaraya swiftly followed up on the issuance of the Republic of Indonesia Minister of Regulation No. 23 of 2015 concerning the Education Growth of Literacy Culture. Reading activities prove that the SMP Muhammadiyah Palangkaraya obeys instructions from the Indonesian Ministry of Education and Culture. The observance is also evident from the fact that SMP Muhammadiyah Palangkaraya allocates 40 directly minutes for reading activities and the Koran before the lessons. Related to the technical activities of Activities Reading, SMP Muhammadiyah Palangkaraya follows the guidelines given by the Ministry of Education and Culture of the Republic of Indonesia.

Parent's participation in the implementation of the school literacy program at Muhammadiyah School Palangka Raya Middle, thanks to the school's efforts to involve the parents of students. The existence group forums of social media such as WhatsApp, report cards distribution meetings used by schools to attract participation from parents in supporting school activities. Active participation of all school members in the implementation of school literacy programs. Starting from the principal to students actively involved in every activity. Students always follow the literacy activities that are given. The teacher or homeroom teacher carries out literacy activities in their class. Library staff always try to provide services to library visitors. The school principal even support by giving a book prize. They are not only limited to their duties but they also do whatever can be done. Including directing students who are free time to read books in the library.

A large number of posters on display, bulletin boards, and slogans supporting literacy culture in the environment school directly or indirectly support literacy culture. The existence of many readings can be stimulating to want to read it, thereby increasing reading interest.

Regarding other supporting factors, schools have allocated funds to support the implementation of school literacy programs such as library maintenance budgets, guardian meetings student, and for the awarding of outstanding student prizes. The existence of this budget proves that schools are aware that implementing school literacy programs requires a support budget.

While the inhibiting factors of the implementation of the School Literacy program at SMP Muhammadiyah Palangka Raya such as students still lack the culture of reading and being late to class as an obstacle 
that is often faced by SMP Muhammadiyah Palangka Raya. Even though they have been called as challengers, there are still students who are late entering the class to carry out the School Literacy program. Palangkaraya Muhammadiyah Middle School considered that literacy culture there had not been running optimally.

Teachers still lack literacy culture and are late coming to class. For the maximum implementation of the school literacy program, not only students but also teachers are required to have a literacy culture and arrive on time to school. This is because in instilling value in children, the exemplary aspect of adults is very important (NWS, interview May 14, 2019). The lack of activities on the introduction and habituation of literacy culture because so far the literacy activities in SMP Muhammadiyah Palangka Raya are still very few. Also there are no special activities or events related to literary culture in SMP Muhammadiyah Palangka. The lack of activities such as the commemoration of discourse days, writing competitions is still very rare in schools. Regarding other perceived inhibiting factors, namely the time to read a book is still lacking and is felt not to be maximal. The 40 minutes available are felt to be lacking because they are also used for reading the Koran and reading books.

\section{School Solutions in Overcoming Barriers}

\section{to School Literacy Program} Implementation in SMP Muhammadiyah

\section{Palangkaraya}

The solution is done by schools in overcoming obstacles in implementing Literacy programs School. Muhammadiyah Palangka Raya Middle School established communication forums such as regular meetings teacher followed by principals, teachers, and employees of the Muhammadiyah Middle School Palangka Raya. This meeting is held every month. This meeting aims to discuss everything related to the sustainability of learning activities, evaluations, policies, and school programs whose goal is ultimately to improve student achievement. When the meeting is reminded for the homeroom teacher to come on time and bring the student attendance sheet when entering class. Students are also reminded to be disciplined and not arrive late.

The student's study is a forum that brings together the school (school principal, Teachers, and employees) and parents. The study was routinely conducted during the warning Islamic day or once every 4 months. In addition to being filled with religious lectures, also The delivery of some information from the school to parents. Usually after a lecture Parents are heading to class. Parents will receive information related to Learning outcomes and student activities. The school communicates to parents about 
Literacy activities, including asking parents to facilitate their children by providing Reading books to be brought to school due to the literacy activities in the assessment category Attitude skills in Rapport. The parents ' group in social media is a means of communication between the class With parents belonging to each class. Usually the community is a group in the media Like Whatsapp.

The Paguyuban is managed by the class and serves to Information from the school to the parent or parents. Includes things Information relating to the activities of the GLS program implementation. Notification letter to inform parents or guardians of a few things Pupils. In addition to direct and social media meetings, delivering information from school Parents can by mail.

This letter will be presented to his guardian at home Through students. Through this letter the school conveys various things to know By the student Guardian. Through this letter also the school can inform the parents that his son 3 The school and as a written rebuke to parents to later his parents To accompany the children to be diligent and timely to the school. Existence Various media and communication forums above as the Solusi Overcome the barriers to implementing the school Literacy Movement Program, indicating As a school effort to establish communication between teachers and parents. Communication Very important for every school activity, especially the implementation of school literacy Runs smoothly and parents of students can actively participate in supporting it.

\section{CONCLUSION}

Implementation of this program utilizes various means of communication and supported by (Human, budget, equipment, and time), commitment, and organizational structure. Moreover Can increase students interest in 15 minutes daily, the form of school readiness in the Implementing school literacy, the role of teachers in school literacy aimed at developing Understanding through the Reading book, the confidence of students in the classroom when Learning and school efforts in growing read interest through school literacy. Contributing factors to school literacy at SMP Muhammadiyah Palangka Raya consist of School Citizen awareness of the importance of literacy culture, Permendikbud RI Obedience No. 23 of 2015 about character growth and school literacy Guide, parental participation, The participation of school citizens, numerous posters, mading and slogans as supporting the culture of literacy in and school budget allocation (APBS). While the factors that inhibit implementation School literacy programs such as low-culture students read and late in class, teachers still Poor in the literary and late culture of the class, the lack of an introductory event and

Cultural literacy, as well as the time to read books still lacking. Solutions conducted 
by the school in overcoming the barriers to implementation of the program School literacy at SMP Muhammadiyah Palangka Raya is building a communication forum such as Routine meetings of teachers, student guardians studies, parents ' groups in social media and notification letters.

Hopefully, the school maximizes the activities of cultural introductions and habituation School literacy. Teachers more intensify student work by creating worksheets or portfolios (clippings) as well as the students ' rubric after vigorous reading so that the school literacy program is not limited only to reading activities But there is sustainability for students. Then the cultural level of literacy teachers is more repaired for optimal school literacy implementation and better discipline Accompanying students. The Government of the Education Office and the Ministry of Indonesian culture to improve attention to the provision of facilities School libraries and book procurement assistance for schools.

\section{REFERENCES}

[1] Emi, M. (2015). Budaya Baca di Era Digital. Lembaga Ladang Kata.

[2] Gewati, M. (2016). Minat Baca Indonesia Ada Di Urutan Ke-61 Dunia. http://edukasi.kompas.com/read/2018/08/29/ 07175131/minat.baca.indonesia .ada.di.urutan.ke-60.dunia

[3] Hidayatullah.P, R. (2019). Survei Kualitas Pendidikan PISA 2018: RI Sepuluh Besar dari Bawah. https://news.detik.com/berita/d4808456/survei-kualitas-pendidikan-pisa2018-ri-sepuluh-besar-dari-bawah/2

[4] Kalida, M. \& M. M. (2015). Gerakan Literasi
Mencerdaskan Negeri. Aswaja Pressindo.

[5] Kemendikbud. (2016). Panduan Gerakan Literasi Sekolah. Dirjen Dikdasmen Kemendikbud RI.

[6] Lestari, P. dan S. (2016). Membangun Karakter Siswa Melalui Kegiatan Intrakurikuler, Ekstrakurikuler dan Hidden Curriculum di SD Budi Mulia Dua Pandeansari Yogyakarta. Jurnal Penelitian, Volume 10.

[7] Lion, E. dan H. Y. B. (2013). Metodologi Penelitian Kualitatif. Jenggala Pustaka Utama.

[8] Moser, A., \& Korstjens, I. (2018). Series: Practical guidance to qualitative research. Part 3: Sampling, data collection and analysis. European Journal of General Practice.

[9] Rohman, A. (2012). Kebijakan Pendidikan: Analisis Dinamika Formulasi dan Implementasi. Aswaja Pressindo.

[10] Romdhoni Ali. (2013). Alquran dan Literasi. Linus Literatur Nusantara.

[11] Saefulloh, A. (2018a). Muhasabah Sebagai Upaya Rehabilitasi Eks-Pecandu Narkoba Di Yayasan Suci Hati Padang. Nidhomul Haq: Jurnal Manajemen Pendidikan Islam. https://doi.org/10.31538/nidhomulhaq.v3i1.1 01

[12] Saefulloh, A. (2018b). Penggunaan Aplikasi Whatsapp Sebagai Metode Pembelajaran di SMP IT Nurul Ilmi Jambi. Jurnal AnNahdhah, 12(2), 126-145.

[13] Saefulloh, A. (2018c). Peran Pendidik Dalam Penerapan Internet Sehat Menurut Islam. AlTadzkiyyah: Jurnal Pendidikan Islam. https://doi.org/10.24042/atjpi.v9i1.2709

[14] Setiawan, F., \& Saefulloh, A. (2019). Kolaborasi Yang Dilaksanakan di Kawasan Wisata Dermaga Kereng Bangkirai Kota Palangka Raya. Administratio: Jurnal Ilmiah Administrasi Publik Dan Pembangunan. https://doi.org/10.23960/administratio.v10i2. 95

[15] Subarsono. (2008). Analisis Kebijakan Publik Konsep, Teori dan Apikasi. Pustaka Pelajar.

[16] Sudiyono. (2007). Formulasi ke Implementasi Kebijakan Pendidikan. Buku Ajar. 
[17] Supiandi, M.I \& Julung, A. (2016). Pengaruh Model Problem Based Learning (PBL) terhadap Kemampuan Memecahkan Masalah dan Hasil Belajar Kognitif Siswa Biologi SMA. Jurnal Pendidiikan Sains, 4(2), 60-64. http://journal.um.ac.id/index.php/jps/.

[18] Suprayitno, S., Tulis, R. S., \& Zuraida, I. (2019). The Strategy to Increase the Regional Revenue (PAD) of the Government of Central Kalimantan through the Governor Regulation No. 16/2018. Policy \& Governance Review. https://doi.org/10.30589/pgr.v2i3.100

[19] Tilaar, H. A. R. \& N. R. (2008). Kebijakan Pendidikan. Pustaka Pelajar.

[20] Wiedarti, P. (2016). Desain untuk Gerakan Literasi Sekolah. Keendikbud. 